\title{
Entrepreneurial Orientation dalam kewirausahaan dan Inovasi Terbuka
}

\section{Vachry Arfansyah Imang}

\section{Vachryimang03@gmail.com}

Entrepreneurial Orientation sendiri menurut (Lorca, Cury, Avrichir, \& Ilan, 2020), jurnal ini mengambil beberapa referensi untuk penjelasan orientasi kewirausahaan. EO mengacu pada orientasi strategis organisasi dan mencakup beberapa aspek gaya pengambilan keputusan, metode, dan praktik mereka. Sejak artikel mani oleh Miller, EO telah dipandang sebagai salah satu konsep terpenting dalam bidang kewirausahaan. Konsep EO sendiri berawal untuk menjelaskan, dalam istilah mudah dan perilaku, arti dari perusahaan menjadi wirausaha. Untuk open innovation menurut (Lyu, Zhu, Han, He, \& Bao, 2020) Inovasi terbuka adalah tujuan penggunaan arus yang masuk dan arus yang keluar pengetahuan untuk percepatan suatu inovasi internal dan juga memperluas pasar untuk penggunaan eksternal inovasi, masing-masing. Menurut tata (Fakhfakh \& Jarboui, 2020) kelola risiko memoderasi baik hubungan antara pengungkapan tepat waktu dan manajemen laba dan hubungan antara manajemen laba dan risiko audit. Dengan kata lain, peran mediasi dari manajemen laba bervariasi tergantung pada tingkat tata kelola risiko.

Pada jurnal pertama (Pratono, Network structure and open innovation:the role of trust in product development, 2018) variabel yang digunakan Social capital theory, The dynamic capability, Operational definition, dan Hypothesis development, salah satu variabel yaitu Social capital theory memandang bahwa suatu jaringan hubungan yang baik akan memberikan nilai kerja sama antar kelompok dan individu. Sedangkan pada jurnal ke dua (Pratono, Does firm performance increase with risk-taking behavior under information, 2018) Terdapat empat variabel laten yaitu perilaku pengambilan risiko, kinerja perusahaan, kapabilitas harga dan turbulensi teknologi informasi. Ukuran untuk masing-masing membangun langkah-langkah subjektif yang diadopsi, yang menjadi strategi penelitian untuk mengatasi, kapasitas yang buruk atau pengungkapan informasi keuangan swasta dari UKM. Terdapat juga pilot test dan juga data caollection.

\section{References}

Fakhfakh, I., \& Jarboui, A. (2020). Audit certification, earnings management and risk governance: a moderated-mediation analysis. Journal of Financial Reporting and Accounting , 18 (2).

Lorca, Cury, M. C., Avrichir, \& Ilan. (2020). Entrepreneurial Orientation and International Fundraising by Civil Society Organizations. Brazilian Business Review, English edition , XVII (2), 169-191. 
Lyu, Y., Zhu, Y., Han, S., He, B., \& Bao, L. (2020). Open innovation and innovation "Radicalness"-the moderating effect of network embeddedness. Technology in Society, 62, 2.

Pratono, A. H. (2018). Does firm performance increase with risk-taking behavior under information. The Journal of Risk Finance , 19 (4), 361-378.

Pratono, A. H. (2018). Network structure and open innovation:the role of trust in product development. Int. J. Business Innovation and Research, 18 (1), 44-61. 